\title{
Biphasic Stridor Related to a Congenital Vallecular Cyst
} Konjenital Vallekula Kisti ile Illgili Bifazik Stridor

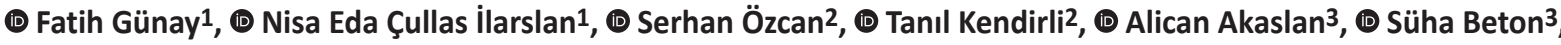 \\ (1) Nazan Çobanoğlu4 \\ ${ }^{1}$ Ankara University Faculty of Medicine, Department of Pediatrics, Ankara, Turkey \\ ${ }^{2}$ Ankara University Faculty of Medicine, Department of Pediatrics, Division of Pediatric Intensitive Care, Ankara, Turkey \\ ${ }^{3}$ Ankara University Faculty of Medicine, Department of Otolaryngology, Ankara, Turkey \\ ${ }^{4}$ Ankara University Faculty of Medicine, Department of Pediatrics, Division of Pediatric Pulmonology, Ankara, Turkey
}

\section{Abstract}

Congenital vallecular cyst (VC) is a rare but potentially fatal pathology in neonates and infants. It usually manifests with symptoms such as stridor, apnea and cyanosis that develop shortly after birth. Stridor is the most common encountered symptom. VC is frequently accompanied by laryngomalacia (LM) and LM is the most common cause of stridor in infants. Diagnosis can be made by flexible laryngoscopy or bronchoscopy. Surgery is the mainstay for VC treatment. Here we present an infant who had respiratory distress, biphasic stridor and cyanosis worsened during feeding and crying, and diagnosed VC. The respiratory symptoms of the patient recovered rapidly after surgical resection.

Key Words: Flexible Bronchoscopy, Infant, Respiratory Distress, Stridor, Vallecular Cyst

\section{Öz}

Konjenital vallekula kisti (VK) yenidoğanlarda ve bebeklerde nadir görülen ancak potansiyel olarak ölümcül bir patolojidir. Genellikle doğumdan kısa bir süre sonra ortaya çıkan stridor, apne ve siyanoz gibi semptomlarla kendini gösterir. Stridor en sık karşılaşılan semptomdur. VK'ye sıklıkla laringomalazi (LM) eşlik eder ve LM, bebeklerde en sık görülen stridor nedenidir. Teşhis fleksible laringoskopi veya bronkoskopi ile yapılabilir. Cerrahi, VC tedavisinin temelini oluşturur. Burada solunum sıkıntısı olan, beslenme ve ağlama sırasında bifazik stridor ve siyanozu kötüleşen ve VK tanısı konan bir süt çocuğu sunulmuştur. Cerrahi rezeksiyon sonrası hastanın solunum semptomları hızla düzelmiştir.

Anahtar Kelimeler: Fleksibı Bronkoskopi, Süt Çocuğu, Solunum Sıkıntısı, Stridor, Vallekula Kisti

\section{Introduction}

Congenital vallecular cyst (VC) is a rare condition in infants but it can lead to various symptoms and even deaths in newborns and infants by obstructing upper respiratory tract (1). Clinical presentation may manifest feeding difficulties and/ or respiratory distress such as stridor, apneas, cyanosis, chest wall retraction and increase effort of breathing $(2,3)$. Stridor is the most common encountered symptom (4). Symptoms of $\mathrm{VC}$ usually begin to appear at birth or in the first few weeks of life $(5,6)$. Congenital laryngeal cysts are estimated at 1.87-3.49 cases per 100,000 live births, of which about 10.5\% constitute
VC (7-9). Laryngomalacia (LM) is the most common cause of stridor in infants. Because of the resemblance of symptoms and frequent co-existence with $L M, V C$ is often misdiagnosed as $L M$ which can lead to delay in diagnosis $(2,10,11)$. In this case report, we present an infant who had diagnosed VC.

\section{Case Report}

A 55-day-old girl was referred from another hospital to our pediatric intensive care unit (PICU) with the preliminary diagnosis of pneumonia and LM not responded to antibiotic treatment and invasive mechanical ventilation for 17 days.

Address for Correspondence/Yazışma Adresi: Fatih Gunay, M.D.,

Ankara University Faculty of Medicine, Department of Pediatrics, Ankara, Turkey

Phone: +90-312-595-5763 E-mail: drfatgun@hotmail.com ORCID ID: orcid.org/0000-0003-2051-8176

Received/Geliş Tarihi: 21.06.2019 Accepted/Kabul Tarihi: 14.08.2019

๑Copyright 2019 Ankara University Faculty of Medicine

Journal of Ankara University Faculty of Medicine is published by Galenos Publishing House.

All content are under CC BY-NC-ND license. 
She was a normal delivered baby at 37 weeks of gestation after an uneventful pregnancy with a birth weight of $3600 \mathrm{gr}$. She presented with respiratory distress and cyanosis worsened during feeding and crying for 3 days when she was 38-day-old, although she developed stridor in the third week of her life. On examination her weight was $3000 \mathrm{gr}$, height was $50 \mathrm{~cm}$. with body temperature $36.6^{\circ} \mathrm{C}$, hearth rate 140 /minute, respiratory rate $25 /$ minute, and $88 \%$ oxygen saturation with pulse oxymeter. She had biphasic stridor, suprasternal and subcostal retractions, and bilateral crackles were heard in both lung fields. Hypercapnia $\left(\mathrm{pCO}_{2}=50 \mathrm{mmHg}\right)$ was detected with blood gas analysis. Chest $\mathrm{X}$-ray revealed bilateral infiltration at lower zones. She was put on intravenous antibiotic and non-invasive ventilation support with nasal continuous positive airway pressure therapy after hospitalization in PICU. As many weaning attempts from noninvasive ventilation support were failed with severe stridor and cyanosis episodes, she was assessed by pulmonary computed tomography (CT) angiography for vascular ring with normal findings. Neck CT imaging reported a thickness at the left side of the aryepiglottic fold. Flexible bronchoscopy revealed a VC obstructing the respiratory tract (Figure 1). VC was resected and histopathological examination confirmed the diagnosis. All her symptoms were relieved postoperatively. As the patient was lost to follow up, it is not known whether she is still asymptomatic and growing well or not. Informed consent was obtained from patient's parent.

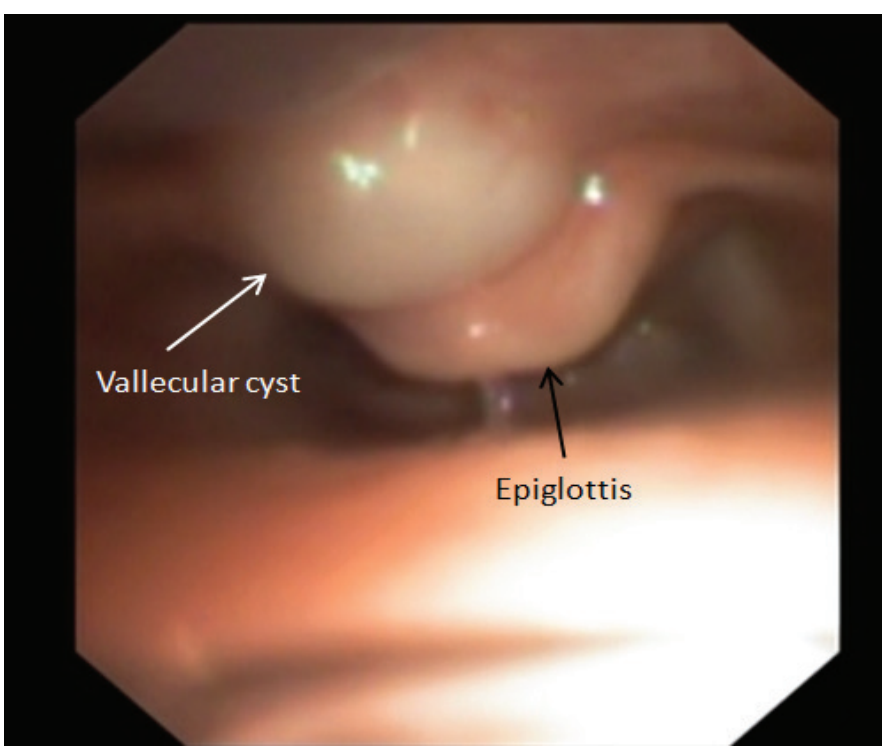

Figure 1: Flexible bronchoscopy image of upper airway showing a vallecular cyst

\section{Discussion}

Congenital laryngeal cyst is a rare clinical condition. Approximately 100,000 live births occur in 1.87-3.49 cases $(7,8)$. Approximately $10.5 \%$ of congenital laryngeal cyst cases are formed by VC (10). De Santo et al. (12), divided congenital laryngeal cysts into saccular and ductal types and VC is classified in ductal cysts and are also known as mucus retention cysts that arise when ductal cysts accumulate in the mucus together with the obstruction of the submucosal gland collecting duct. In the study conducted by Tsai et al. (10), the annual incidence of VC is estimated to be 5.3 cases per 100,000 live births. In other studies, the incidence of $\mathrm{VC}$ in congenital stridor cases was only 0.9-2.0 percent $(13,14)$.

Stridor is the most common encountered symptom of VC (4). Generally, an inspiratory stridor suggests airway obstruction above the glottis while an expiratory stridor is indicative of obstruction in the lower trachea, and a biphasic stridor suggests a glottic or subglottic lesion (15). Although most of the patients reported in literature with VC were presented with inspiratory stridor, our patient presented with biphasic stridor.

Other symptoms of VC include dyspnoea, cyanosis, retractions, and feeding difficulties (1). Failure to thrive is an unusual presentation of VC (16). Although progressive stridor and cyanotic episodes, worsened during feeding and crying, were the most prominent initial complaints of our case, she was also below the $3^{\text {rd }}$ percentile according to growth chart.

LM is the most common congenital anomaly of the larynx, and it is the most important cause of stridor in children under 6 months of age. Vascular ring and other anatomical or functional anomalies of airways like subglottic stenosis and vocal cord paralysis are among differential diagnosis of stridor in infants and newborns $(17,18)$. Neck CT is a valuable method for detecting patologies such as thyroglossal duct cyst, dermoid cyst, hemangioma, lymphangioma, and $\mathrm{VC}$, and all of them have similar appearance with low-density image in CT (19). Our case was investigated with pulmonary CT angiography and neck CT imaging, but vascular ring or any other airway problems could not be detected. Although neck CT imaging of our patient revealed a thickness at the left side of the aryepiglottic fold, a clear diagnosis could not be made. This may be related to movement and respiration artifacts.

Endoscopy is indicated as the gold standard in the definitive diagnosis of laryngeal cysts in patients with persisting symptoms by using either a laryngoscope or a bronchoscope (20). For our patient, a flexible bronchoscopy was performed through nasal route by pediatric pulmonology specialist for laryngeal evaluation and VC was detected.

Surgery is the mainstay for $\mathrm{VC}$ treatment but recurrence was reported in the literature $(20,21)$. Our patient's symptoms were relieved immediately after resection of $\mathrm{VC}$. As the patient was lost to follow up, it is not known whether she is still asymptomatic and growing well or not. 


\section{Conclusion}

Despite LM is the most common condition that can cause stridor and respiratory distress in infants, VC should be kept in mind in the differential diagnosis. Although generally, an inspiratory stridor suggests airway obstruction above the glottis while a biphasic stridor suggests a glottic or subglottic lesion, we have documented a VC presented with biphasic stridor in an infant which may be an exception that prove the rule.

\section{Ethics}

Informed Consent: Informed consent was obtained from patient's parent

Peer-review: Externally peer-reviewed.

\section{Authorship Contributions}

Concept: N.Ç., T.K., Design: N.Ç., F.G., N.E.Ç.I., Data Collection or Processing: F.G., N.E.Ç.I., A.A., S.Ö., Analysis or Interpretation: N.Ç., S.B., T.K., F.G., Literature Search: N.Ç., F.G., N.E.Ç.I., Writing: N.Ç., F.G., T.K., N.E.Ç.I., S.Ö., A.A., S.B.

Conflict of Interest: No conflict of interest was declared by the authors.

Financial Disclosure: The authors declared that this study received no financial support.

\section{References}

1. Mitchell DB, Irwin BC, Bailey CM, et al. Cysts of the infant larynx. J Laryngol Otol. 1987;101:833-837.

2. Gutierrez JP, Berkowitz RG, Robertson CF. Vallecular cysts in newborns and young infants. Pediatr Pulmonol. 1999;27:282-285.

3. Hsieh WS, Yang PH, Wong KS, et al. Vallecular cyst: an uncommon cause of stridor in newborn infants. Eur J Pediatr. 2000;159:79-81.

4. Tuncer U, Aydogan LB, Soylu L. Vallecular cyst: a cause of failure to thrive in an infant. Int J Pediatr Otorhinolaryngol. 2002;65:133-135.
5. Khashu M, Osiovich $\mathrm{H}$, Kozak F, et al. Congenital epiglottic cyst presenting with severe airway obstruction at birth. J Perinatol. 2006;26:71-72.

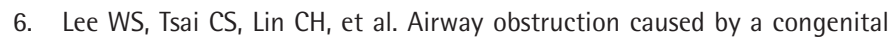
epiglottic cyst. Int J Pediatr Otorhinolaryngol. 2000;53:229-233.

7. Pak MW, Woo JK, Van Hasselt CA. Congenital laryngeal cysts: current approach to management. J Laryngol Otol. 1996;110:854-856.

8. Prowse S, Knight L. Congenital cysts of the infant larynx. Int J Pediatr Otorhinolaryngol. 2012;76:708-711.

9. Arens C, Glanz H, Kleinhasser 0. Clinical and morphological aspects of laryngeal cysts. Eur Arch Otorhinolaryngol. 1997;254:430-436.

10. Tsai YT, Lee LA, Fang TJ, et al. Treatment of vallecular cysts in infants with and without coexisting laryngomalacia using endoscopic laser marsupialization: fifteen-year experience at a single-center. Int J Pediatr Otorhinolaryngol. 2013;77:424-428.

11. Sands NB, Anand SM, Manoukian JJ. Series of congenital vallecular cysts: a rare yet potentially fatal course of upper airway obstruction and failure to thrive in the newborn. Otolaryngol Head Neck Surg. 2009;38:6-10.

12. De Santo LW, Devine KD, Weiland LH. Cysts of the larynx-Classification. Laryngoscope. 1970;80:145-176.

13. Birch DA. Laryngeal stridor in infants and children: a study of 200 cases. J Laryngol Otol. 1961;75:833-840.

14. Holinger LD. Etiology of stridor in the neonate, infant and child. Ann Otol Rhinol Laryngol. 1980;89:397-400.

15. Leung AK, Cho H. Diagnosis of stridor in children. Am Fam Physician. 1999;60:2289-2296.

16. Oluwole M. Congenital vallecular cysts: a cause of failure to thrive. Br J Clin Pract. 1996;50:170.

17. Zoumalan R, Maddalozzo J, Hollinger LD. Etiology of stridor in infants. Ann Otol Rhinol Laryngol. 2007;116:329-334.

18. Koch BL. Cystic malformations of the neck in children. Pediatr Radiol. 2005;35:463-477.

19. Lev S, Lec MH. Imaging of cystic lesions. Radiol Clin North Am. 2000;38:10131027.

20. Leibowitz JM, Smith LP, Cohen MA, et al. Diagnosis and treatment of pediatric vallecular cysts and pseudocysts. Int J Pediatr Otorhinolaryngol. 2011;75:899-904.

21. Chen EY, Lim J, Boss EF, et al. Transoral approach for direct and complete excision of vallecular cysts in children. Int J Pediatr Otorhinolaryngol. 2011;75:1147-1151. 